\title{
Down's syndrome is strongly associated with coeliac disease
}

\author{
L Gale, H Wimalaratna, A Brotodiharjo, J M Duggan
}

\begin{abstract}
Background-There is evidence of an increased prevalence of coeliac disease in Down's syndrome.

Aims-To investigate the association, patients with Down's syndrome and matched controls were examined.

Methods-Fifty nine patients with Down's syndrome residing in government institutions in the Hunter region of New South Wales were studied. Four were excluded (terminally ill=1, uncooperative=3). Each of 55 patients was matched for age, sex, and residence with a control patient. Patients with both positive IgA and IgG antigliadin antibodies were considered for endoscopical duodenal biopsy.

Results-Twenty one patients and two controls had raised IgA and IgG antibodies $\left(x^{2}=19 \cdot 4 ; p<0 \cdot 001\right)$. Tissue was obtained in 18 patients. Two had characteristic flat, five pronounced lymphocytic infiltration not diagnostic of coeliac disease, two giardiasis, and eight were normal. In one the tissue was not suitable for analysis. There were few differences between the subgroups in their anthropomorphic, biochemical, or haematological findings.
\end{abstract}

Conclusions-The prevalence of coeliac disease in these 51 patients with Down's syndrome is at least two $(3.9 \%$; $95 \%$ confidence interval (95\% CI) $0 \%-9 \cdot 2 \%$ ) and could be as many as seven $(13.7 \% ; 95 \%$ CI $4 \cdot 3 \%-23 \cdot 2 \%$ ). In this community the prevalence of coeliac disease in Down's syndrome is increased more than $\mathbf{1 0 0}$-fold ( $\times 135-473)$.

(Gut 1997; 40: 492-496)

Keywords: coeliac disease, Down's syndrome, antigliadin antibodies, biopsy of the small bowel, $\mathrm{T}$ cells.

Stockton Centre,

Stockton

L Gale

Gastroenterology Unit, John Hunter Hospital, Locked Bag No 1, Hunter Region Mail Centre NSW 2310, Australia

H Wimalaratn

A Brotodiharjo

J M Duggan

Correspondence to: Assistant Professor J M Duggan,

Princeton Medical Centre 60 Lindsay Street, Hamilton NSW 2303 Australia.

Accepted for publication 14 October 1996

The association between coeliac disease and Down's syndrome is now well established. The earliest reports were case study approaches which described the coexistence of the two conditions in a few patients. ${ }^{1-7}$ As this association could occur by chance, of more surveyed larger populations, either of known cases of coeliac disease ${ }^{8} 9$ or known cases of Down's syndrome ${ }^{10}$ in an effort to estimate prevalence of the combined conditions. One study ${ }^{9}$ suggested an increased prevalence of coeliac disease in Down's syndrome of
43 times that of other children; another ${ }^{10}$ suggested a 20 -fold increase.

The next progression has been to prospectively survey populations of patients with Down's syndrome, using antibody screening tests to determine eligibility for biopsy. ${ }^{11-16} \mathrm{It}$ is difficult to draw conclusions about the strength of the association between coeliac disease and Down's syndrome from these studies because of the lack of comparability in the findings (Table I). The patients have differed in age; the representativeness of the sample is not always clear; not all studies have control groups; there are differences in screening methods and criteria for biopsy selection; and most studies have failed to biopsy all those identified by the screening process. Prevalence figures have ranged from $3 \%$ to $7 \%$ and would seem to be an underestimate in most cases.

These studies have also raised the question of the reliability of antibody testing, particularly antigliadin antibodies. Between $24 \%$ and $50 \%$ of those biopsied were found to have coeliac disease, indicating that most antibody results were "false positives". The more recent studies have indicated that the antiendomysial antibodies are more accurate than antigliadin antibodies in determining selection for biopsy. ${ }^{1516}$

The present study was undertaken to examine these issues in more detail. The questions of concern were:

- Is there an increased frequency of antigliadin antibodies in those with Down's syndrome?

- Is there an increased incidence of coeliac disease in those with Down's syndrome?

- Is the antigliadin antibody test a reliable screening device for this group of people?

The study focuses on the serological and biopsy findings in an institutionalised population of adults with Down's syndrome.

\section{Methods} relevance were studies which retrospectively
PATIENTS

The patients were 59 adults with Down's syndrome who resided in the three campuses of the Hunter Region Developmental Disability Service, the largest government institution for people with intellectual disability in New South Wales, Australia. The diagnosis patients, severely disabled and institutionalised for most of their lives, ranged in age from 25 control group was matched with the Down's was confirmed by chromosome analysis. The to 62 (mean 37) years; 28 were women. A 
TABLE I Major findings of studies which have screened for coeliac disease in populations of patients with Down's syndrome

\begin{tabular}{|c|c|c|c|c|c|c|c|c|c|c|}
\hline \multirow[b]{2}{*}{ Author } & \multirow[b]{2}{*}{$n$} & \multirow[b]{2}{*}{$\begin{array}{l}\text { Age } \\
\text { group }\end{array}$} & \multirow[b]{2}{*}{ Selection criteria } & \multirow[b]{2}{*}{$\begin{array}{l}\text { Control } \\
\text { group }\end{array}$} & \multicolumn{2}{|c|}{ Screening methods and results } & \multirow[b]{2}{*}{$\begin{array}{l}\text { Biopsy selection } \\
\text { criteria }\end{array}$} & \multirow{2}{*}{$\begin{array}{l}\text { Biopsies } \\
\text { able to } \\
\text { be done } \\
(\%)\end{array}$} & \multirow{2}{*}{$\begin{array}{l}\text { Biopsy } \\
\text { specimens } \\
\text { positive } \\
\text { for } C D \\
(\%)\end{array}$} & \multirow{2}{*}{$\begin{array}{l}C D \text { in } \\
\text { whole } \\
\text { sample } \\
(\%)\end{array}$} \\
\hline & & & & & Test & $\begin{array}{l}\text { Positive } \\
\text { (\%) }\end{array}$ & & & & \\
\hline Reading $1984^{11}$ & 17 & $?$ & $?$ & No & $\begin{array}{l}\text { Gluten antibodies } \\
\text { Alphagliadin antibodies }\end{array}$ & $\begin{array}{l}47 \\
44\end{array}$ & $\begin{array}{l}\text { No biopsies } \\
\text { performed }\end{array}$ & - & - & - \\
\hline $\begin{array}{l}\text { Kanavin et al } \\
1988^{12}\end{array}$ & 38 & $\begin{array}{l}\text { Mostly } \\
\text { adults }\end{array}$ & $\begin{array}{l}\text { All DS patients in } \\
\text { local institutions }\end{array}$ & Yes & $\begin{array}{l}\text { Antigliadin IgA } \\
\text { Antigliadin IgG }\end{array}$ & $\begin{array}{c}58 \\
?\end{array}$ & $\begin{array}{l}\text { Those "with the } \\
\text { highest" IgA } \\
n=7\end{array}$ & 32 & 29 & 5 \\
\hline Storm $1990^{13}$ & 78 & Children & $?$ & Yes & $\begin{array}{l}\text { Antigliadin IgA } \\
\text { Antigliadin IgG }\end{array}$ & $\begin{array}{r}3 \\
29\end{array}$ & $\begin{array}{l}\text { Positive results } \\
\text { on both tests } \\
n=6\end{array}$ & 67 & 50 & 3 \\
\hline $\begin{array}{l}\text { Castro et al } \\
1993^{14}\end{array}$ & 155 & Children & $?$ & Yes & Antigliadin IgA & 26 & $\begin{array}{l}\text { Positive IgA } \\
\mathrm{n}=41\end{array}$ & 51 & 33 & 5 \\
\hline $\begin{array}{l}\text { Zubillaga et al } \\
1993^{15}\end{array}$ & 70 & Children & $\begin{array}{l}\text { All DS patients } \\
\text { attending a local } \\
\text { child health clinic }\end{array}$ & No & $\begin{array}{l}\text { Antigliadin IgA } \\
\text { (if }+ \text {, then } \\
\text { antiendomysial) }\end{array}$ & 13 & $\begin{array}{l}\text { Positive IgA } \\
\mathrm{n}=9\end{array}$ & 89 & 36 & 4 \\
\hline $\begin{array}{l}\text { George et al } \\
1995^{16}\end{array}$ & 115 & Children & $?$ & No & $\begin{array}{l}\text { Antigliadin IgA } \\
\text { Antiendomysial } \\
\text { Antireticulin } \\
\text { Lactulose/mannitol }\end{array}$ & $\begin{array}{r}29 \\
6 \\
4 \\
17\end{array}$ & $\begin{array}{l}\text { Positive result } \\
\text { on any one of } \\
\text { the four tests } \\
n=43\end{array}$ & $\begin{array}{l}79 \\
(100 \% \\
\text { of those } \\
\text { antibody }+ \text { ) }\end{array}$ & 24 & 7 \\
\hline
\end{tabular}

DS=Down's syndrome. $\mathrm{CD}=$ coeliac disease.

syndrome group on the basis of age (within five years), sex, and residential unit within each campus. Consent to the procedures was given by the person or bodies responsible for the patients under the Disability Services and Guardianship Act, 1987 (natural guardian, Guardianship Board, or the Public Guardian).

\section{METHODS}

\section{Blood collection}

Blood samples were collected from 55 of the 59 in the Down's syndrome group and their 55 matched controls. Three patients with Down's syndrome were uncooperative and would not allow venepuncture and one with a terminal illness was excluded. The samples were sent to two different laboratories as each campus did not use the same pathology provider. The two laboratories used different kits for the determination of antigliadin antibodies (KabiPharmacia Uppsala, Sweden and Coeliac Screening kit, Medical Innovations, Artarmon, NSW). As well as antigliadin antibodies, haematological and biochemical tests were carried out on the Down's syndrome group using standard techniques.

\section{Biopsies}

Those patients with a positive antigliadin test (defined as above normal concentrations on both antigliadin IgA and antigliadin IgG after excluding IgA deficiency) were examined further. Case histories were prepared including history of diarrhoea, anaemia, and weight loss as well as behavioural characteristics

TABLE II Antigliadin antibody results for patients with Down's syndrome and control patients

\begin{tabular}{llllll}
\hline & $\begin{array}{l}\text { Negative IgA } \\
\text { and IgG } \\
(n(\%))\end{array}$ & $\begin{array}{l}\text { Positive IgA } \\
\text { only } \\
(n(\%))\end{array}$ & $\begin{array}{l}\text { Positive IgG } \\
\text { only } \\
(n(\%))\end{array}$ & $\begin{array}{l}\text { Positive IgA } \\
\text { and IgG } \\
(n(\%))\end{array}$ & Total \\
\hline DS & $17(30 \cdot 9)$ & $3(5 \cdot 5)$ & $14(25 \cdot 5)$ & $21(38)$ & 55 \\
Control & $43(78 \cdot 2)$ & $2(3 \cdot 6)$ & $8(14 \cdot 5)$ & $2(3 \cdot 6)$ & 55 \\
\hline
\end{tabular}

DS=Down's syndrome. (for example, disturbances of mood and behaviour). All those with a positive test result were considered for biopsy whether or not the history and findings suggested coeliac disease. Endoscopic biopsy specimens were taken from as far distal as possible in the duodenum.

\section{Statistical methods}

$\chi^{2}$ Tests were used for categorical data with Yates's correction as appropriate. For normally distributed data $t$ tests with a two-tailed test of significance were used.

\section{Results}

ANTIGLIADIN ANTIBODY TEST

Of the 55 patients with Down's syndrome, 21 had an increase in both IgA and IgG antibodies and a further one had IgA deficiency and raised IgG antibodies compared with only two controls $\left(\chi^{2}=19.4, p<0.001\right.$; Table II $)$. The patient with IgG antibodies and IgA deficiency was included in the positive group for further investigation and analysis. More male (15 of 31) than female (six of 24) patients with Down's syndrome had an increase in both IgA and IgG antibodies $\left(\chi^{2}=4.0, p<0.05\right.$; (Figure).

HAEMATOLOGY AND BIOCHEMISTRY (PATIENTS WITH DOWN'S SYNDROME)

Although a few patients had below normal values for haemoglobin, ferritin, and calcium, most results were within reference values. The exception was albumin: 16 of 54 patients with Down's syndrome tested had low concentrations of albumin. Mean concentrations of albumin in the positive antibody group were $37.6 \mathrm{~g} / \mathrm{l}$ and in the negative antibody group $41.9 \mathrm{~g} / 1(t=-4.3, \mathrm{p}<0.0001)$. Mean values of haemoglobin were significantly lower in antibody positive men but not women $(t=2 \cdot 61$, $\mathrm{p}<0 \cdot 015$; Table III). 


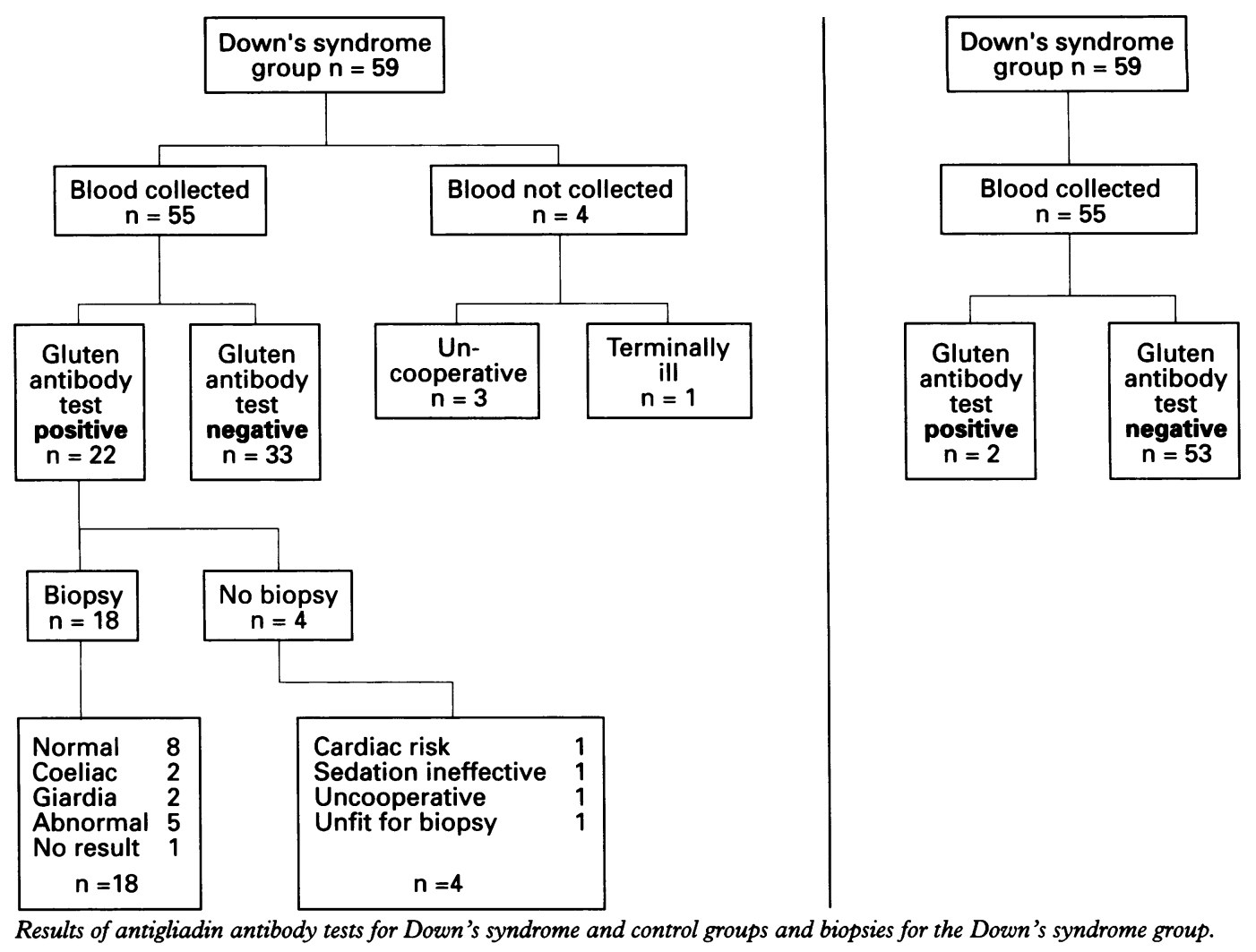

BIOPSY SPECIMENS

Biopsy specimens were obtained from 18 of 22 patients and 17 were interpretable (Figure). Two had unequivocal appearances of coeliac disease, two had giardiasis, in five there was evidence of lymphocytic infiltration of the lamina propria, and eight were histologically normal. The two patients who had coeliac disease diagnosed were placed on gluten-free diets.

OTHER MEASURES

There was a significant difference between patients with Down's syndrome and control patients in height and weight. Patients with Down's syndrome were significantly shorter $(t=5.42, \quad \mathrm{p}<0.001)$ and lighter $(t=3.82$,

TABLE III Summary of investigation results comparing positive and negative antibody subgroups and biopsy normal and biopsy abnormal subgroups

\begin{tabular}{|c|c|c|c|c|}
\hline Investigations & $\begin{array}{l}\text { Positive } \\
\text { antigliadin } \\
\text { antibody test } \\
(n=22)^{\star}\end{array}$ & $\begin{array}{l}\text { Negative } \\
\text { antigliadin } \\
\text { antibody test } \\
(n=33)\end{array}$ & $\begin{array}{l}\text { Normal biopsy } \\
(n=8)\end{array}$ & $\begin{array}{l}\text { Abnormal biopsy } \\
(n=9)\end{array}$ \\
\hline Age & \multicolumn{2}{|c|}{ No differences } & \multicolumn{2}{|c|}{ No differences } \\
\hline Sex & \multicolumn{2}{|c|}{$\begin{array}{l}\text { Higher percentage } \\
\text { of men than } \\
\text { women }\end{array}$} & \multicolumn{2}{|c|}{ No differences } \\
\hline Weight & \multicolumn{2}{|c|}{ No differences } & \multicolumn{2}{|c|}{ No differences } \\
\hline Height & \multicolumn{2}{|c|}{ No differences } & \multicolumn{2}{|c|}{ No differences } \\
\hline $\begin{array}{l}\text { Haematology and } \\
\text { biochemistry }\end{array}$ & \multicolumn{2}{|c|}{$\begin{array}{l}\text { Low albumin and } \\
\text { low haemoglobin } \\
\text { in males }\end{array}$} & \multicolumn{2}{|c|}{ No differences } \\
\hline Clinical symptoms & \multicolumn{2}{|c|}{$\begin{array}{l}\text { Both groups had a large } \\
\text { percentage of subjects with } \\
\text { histories of symptoms such as } \\
\text { diarrhoea, anaemia, and } \\
\text { weight loss }\end{array}$} & \multicolumn{2}{|c|}{$\begin{array}{l}\text { Both groups had a large } \\
\text { percentage of subjects with } \\
\text { histories of symptoms such as } \\
\text { diarrhoea, anaemia, and } \\
\text { weight loss }\end{array}$} \\
\hline
\end{tabular}

^Includes one patient with + antigliadin IgG and IgA deficiency. $\mathrm{p}<0.001)$ than their matched controls. In the Down's syndrome group there was no difference between those with a positive and those with a negative antigliadin antibody test on measures of age, height, or weight, or clinical indications of coeliac disease. Histories of diarrhoea, anaemia, and weight loss were common for the Down's syndrome group as a whole (Table III).

\section{Discussion}

We may now attempt to answer the questions put earlier. Firstly, there is unquestionably an increased prevalence of antigliadin antibodies in Down's syndrome.

The second question, that of the prevalence of coeliac disease in Down's syndrome, requires some exploration. Two patients had unequivocal changes - the classic "flat" biopsy specimen. Seven patients had abnormal biopsy specimens; in two of these giardia organisms were seen and provided adequate explanation for the cellular infiltrate, and in five it is possible but unlikely that they were a response to giardia infestation with a scant population not recognised on microscopy. A much more likely explanation is that they represent the infiltrative lesion described by Marsh, who has vigorously promoted the view that this infiltrative stage represents a response to antigens such as gluten products and which is much more frequent than the classic "flat" biopsy sample. ${ }^{17}$ Many years before, Weinstein noted similar infiltrative appearances in patients with dermatitis herpetiformis culminating in a "flat" biopsy sample in patients given a $20 \mathrm{~g}$ gluten supplement daily for 20 weeks. ${ }^{18}$ This represents a large dose of gluten, 
being equivalent to eating almost a $500 \mathrm{~g}$ loaf of bread daily (Bread Research Institute of Australia, personal communication). Given that the five patients had raised antigliadin antibodies and lymphocytic infiltrates in their lamina propria, and three of them had lowered serum albumin concentrations, it is difficult to escape the conclusion that they, or most of them, had gluten intolerance. If this is so then up to seven of the 18 patients biopsied out of 51 patients adequately examined had coeliac disease. There are strategies to consider to confirm the gluten intolerance of patients such as these five. Rebiopsy after a period of glutenfree diet or after a period of high gluten diet such as that used by Weinstein ${ }^{18}$ might well settle the issue. The caregivers of one of these five have attempted to implement a gluten-free diet, with equivocal results. Compliance with the diet by a severely disabled patient and his multiple caregivers has presented major logistical problems and it is difficult to justify rebiopsy when withdrawal has not been complete. The patient also has cardiac problems which have worsened since the initial biopsy, placing him at risk for procedures requiring sedation. Many of the biopsies were carried out in difficult circumstances, with sedation being difficult to achieve at the usual dosages. It needs to be recognised that endoscopical biopsy on uncooperative adults presented major challenges and pulse oximetry showed, at times, appreciable hypoxaemia. Equally, general anaesthesia was not a feasible alternative.

In summary, the prevalence of coeliac disease in our patients with Down's syndrome is at least two and probably seven of 18 patients biopsied and of 51 of the entry cohort giving a prevalence of at least $3.9 \%(95 \% \mathrm{CI}=$ $0-9 \cdot 2 \%)$ and as much as $13 \cdot 7 \%(95 \% \mathrm{CI}=$ $4 \cdot 3 \%-23 \cdot 2 \%$ ). The prevalence of coeliac disease in the Hunter region is about $29 / 10^{5}$, so the prevalence in Down's syndrome is increased more than 100-fold $(\times 135-473) .{ }^{19}$

The third question, that of the utility of the search for antigliadin antibodies, can be answered with some reservations. The antigliadin IgG test is too sensitive and the antigliadin IgA test a better discriminant.

Our study, like others reported earlier, ${ }^{13-16}$ found many "false positive" antibody results; that is, almost $50 \%$ of antibody positive patients with Down's syndrome had a normal biopsy result. As the control group did not show such a high rate of positivity this is a response specific to the Down's syndrome group. There was little correlation between actual antibody titre and biopsy result; some of the patients with Down's syndrome had very high antibody titres and a normal biopsy specimen. Given the higher number of "false positives" when using antigliadin antibodies with the patients with Down's syndrome compared with controls, we think that antiendomysial antibody is preferable. ${ }^{20}{ }^{21}$ No value in screening patients was seen in standard full blood count, 20 item biochemistry, or serum zinc, carotene, ferritin, folate, and vitamin B12 estimation. None of this explains why gluten intolerance should have an increased prevalence in Down's syndrome. The modern view is that the basic defect in coeliac disease is the presence in gluten of specific amino acid sequences which are processed within the lamina propria and presented by macrophages of specific affinities to coeliac disease to CD4 lymphocytes with a resultant upregulation of cytokine production. This would explain much of the resulting anatomical and physiological changes seen. ${ }^{172-24}$ A synthetic peptide corresponding to amino acids $31-49$ of A gliadin ${ }^{25}$ or amino acids $31-47^{26}$ produces changes in coeliac tissues. Most, if not all, patients with coeliac disease have a cell surface molecule DQw2 and many have DR17. However, a genetic basis for coeliac disease is inadequate - for example, identical twins only show $70 \%$ concordance in coeliac disease ${ }^{27}$ and $25 \%$ of northern European white people exhibit DQw2. A key issue then is the mechanism preventing the development of coeliac disease in nearly all those with the appropriate $\mathrm{MHC} 2$ phenotype and why the mechanism is suboptimal in Down's syndrome. Three potential explanations appear. Firstly, there is evidence of premature aging and loss of $T$ cell function in Down's syndrome ${ }^{28}$ and there is a higher prevalence of immunological disturbances in the condition. ${ }^{212} 29 \mathrm{~A}$ second consideration is early weaning, characteristic of the condition and associated with a five-fold increase in the incidence of coeliac disease. ${ }^{30}$ Thirdly, it is possible that the frequent gastrointestinal infections in such institutionalised patients may lead to an impairment of integrity of the small bowel. In summary, there are no data to explain the high prevalence of coeliac disease in Down's syndrome. Whether the solution lies in more intensive epidemiological studies or in events at a molecular level must remain speculative. Further investigations along these lines are warranted.

The assistance of Janet, Lisa, and Adrian (Clinic Staff, HRDDS) is gratefully acknowledged. We also thank the staff of the Endoscopy Unit, John Hunter Hospital. Both groups made a major contribution. Janelle Czermak is acknowledged for her patience as well as clerical assistance.

1 Bentley D. A case of Down's's syndrome complicated by retinoblastoma and celiac disease. Pediatrics 1975; 56: $131-3$.

2 Levo Y, Green P. Down's syndrome and autoimmunity. Am f Med Sci 1977; 273: 95-9.

3 Nowak TV, Ghishan FK, Schulze-Delrieu K. Celiac sprue in Down's syndrome: considerations on a pathogenetic in Down's syndrome: considerations on
link. $A m$ f Gastroenterol 1983; 78: $280-3$.

4 Howell SJL, Foster KJ, Reckless J. Protracted survival in patients with Down's syndrome. BMf 1983; 287: 1429-30

5 Ruch W, Schümann K, Gordon $\mathrm{P}$, Bürgin-Wolff A Girard J. Coexistent coeliac disease, Graves' disease, and diabetes mellitus type 1 in a patient with Down syndrome. Eur $\mathcal{F}$ Pediatr 1985; 144: 89-90.

6 Iacono G, Cavataio F, Balsamo V, Carroccio A Montalto G, Notarbartolo A. Celiac disease in Down's syndrome: considerations on the role of histocompatisyndrome: considerations on the role of histocompatibility antigens. F Pediatr Gastroenterol Nutr 1990; 10: 273 , syndrome. $f$ Pediatr Gastroenterol Nutr 1991; 13: 121. syndrome. F Pediatr Gastroenterol Nutr 1991; 13: 121 .
Dias JA, Walker-Smith J. Down's syndrome and coeliac disease. $\mathcal{F}$ Pediatr Gastronterol Nutr 1990; 10: 41-3. disease. F Pediatr Gastronterol Nutr 1990; 10: 41-3.
Hilhorst MI, Brink M, Wauters EAK, Houwen RHJ. Down syndrome and coeliac disease: five new cases with a review syndrome and coeliac disease: five new cases with
of the literature. Eur $\mathcal{F}$ Pediatr 1993; 152: 884-7.

10 Similä S, Kokkonen J. Coexistence of celiac disease and Down syndrome. Am f Ment Retard 1990; 95: 120-2.

11 Reading CM. Down's syndrome: nutritional intervention. Nutr Health 1984; 3: 91-111. 
12 Kanavin $\varnothing$, Scott H, Fausa O, Ek J, Gaarder PI, Brandtzaeg P. Immunological studies of patients with Down's syndrome. Acta Med Scand 1988; 224: w73-7.

13 Storm W. Prevalence and diagnostic significance of gliadin antibodies in children with Down syndrome. Eur $f$ Pediatr 1990; 149: 833-4.

14 Castro M, Crinò A, Papadatou B, Purpura M, Giannotti A, Ferretti $F$, et al. Down's syndrome and celiac disease: the prevalence of high IgA-antigliadin antibodies and HLADR and DQ antigens in trisomy 21. $\mathcal{F}$ Pediatr Gastroenterol Nutr 1993; 16: 265-8.

15 Zubillaga P, Vitoria JC, Arrieta A, Echaniz P, GarciaMasdevall MD. Down syndrome and celiac disease. $f$ Pediatr Gastroenterol Nutr 1993; 16: 168-71.

16 George EK, Mearin ML, Bouquet J, von Blomberg BME, Stapel SO, van Elburg RM, de Graaf EA. High frequency
of coeliac disease in Down's syndrome. Gut 1995; 37 (suppl 2 pt 2): A56.

17 Marsh MN. Gluten, major histocompatibility complex and the small intestine. A molecular and immunobiologic approach to the spectrum of gluten sensitivity (celiac sprue). Gastroenterology 1992; 102: 330-54.

18 Weinstein WM, Latent coeliac sprue. Gastroenterology 1974 66: 489-93.

19 Porter NJ, Duggan JM. Epidemiology of coeliac disease in an Australian community. Proceedings of Annual Scientific meeting. Gastroenterology Society of Australia 1989. Aust NZ F Med 1990; 20: 359

20 Corrao G, Corazza GR, Andreani ML, Torchio $P$ Valentini RA, Galatola G, et al. Serological screening of coeliac disease: choosing the optimal procedure according to various prevalence studies. Gut 1994; 35: according
21 Ladinser B, Rossipal E, Pittschieler V. Endomysial antibodies in coeliac disease: an improved method. Gut 1994; 35: 776-8.

22 Cummins AG Pentila IA, Labrooy JT, Robb TA, Davidson GP. Recovery of the small intestine in coeliac disease on a gluten-free diet: changes in intestinal permeability, small bowel morphology and T-cell activity. $\mathcal{F}$ Gastroenterol Hepatol 1991; 6: 53-7.

23 Marsh M, Cummins A. The interactive role of mucosal T lymphocytes in intestinal growth, development, and enteropathy. $\mathcal{G}$ Gastroenterol Hepatol 1993; 8: 270-8.

24 Nilsen EM, Lundkin KEA, Krajci P. Gluten specific HLADQ restricted $T$ cells from coeliac mucosa produce cylokines with $\mathrm{ThI}$ of ThO profile dominated by interferon. Gut 1995; 37: 766-76.

25 Sturgess R, Day P, Ellis HJ, Lundin KE, Gjertsen HA, Kontakou, et al. Wheat peptide challenge in coeliac disease. Lancet 1994; 343: 758-61.

26 Gjertsen HA, Lundin KE, Sollid LM, Eriksen JA Thorsby E. T-cells recognize a peptide derived from Thorsby E. T-cells recognize a peptide derived from
alpha-gliadin presented by the coeliac disease-associated HLA-DQ (alpha $1^{\star} 0501$, beta $1^{\star} 0201$ ) heterodimer. Hum Immunol 1994; 39: 243-52.

27 Kagnoff MF. The genetic basis of coeliac disease: role of HLA genes in coeliac disease. In Marsh MN, ed. Coeliac disease. London: Blackwell, 1992; 215-38.

28 Burgio GR, Nespoli L. Ageing, T lymphocytes, and Down's syndrome. Lancet 1974; ii: 1580.

29 Nespoli L, Burgio GR, Ugazio AG, Maccario R. Immunological features of Down's syndrome: a review. $\mathcal{f}$ Intellect Disabil Res 1993; 37: 543-51.

30 Greco L, Auricchio S, Mayer M, Grimald M. Case control study on nutritional risk factors in coeliac disease. $\mathcal{F}$ Pediatr Gastroenterol Nutr 1988; 7: 395-9. 